\title{
PENGGUNAAN COOPERATIVE LEARNING MODEL JIGSAW DALAM PENINGKATAN AKTIFITAS SISWA PADA PEMBELAJARAN PKn DI SMPN 1 KOTA PARIAMAN
}

\author{
Yulfianti \\ Guru Mata Pelajaran PKn Sekolah Menengah Pertama Negeri (SMPN) 1 Kota Pariaman \\ Email: yulfianti62@yahoo.com
}

\begin{abstract}
This study aimed to increase the student learning activity in Citizenship Education at classroom VIII.5 SMP Negeri 1 of Pariaman City in the 1st half semester of 2015/2016. This study was conducted through Classroom Action Research with the application of the Jigsaw model in cooperative learning. This study was conducted in two cycles. The finding of this study showed that the use of Jigsaw model in Citizenship Education classroom could increase the activity of the learners, the average value of their learning outcomes, and learning completeness of the learners. The conclusion of this study was that there were increased activities in the student learning in Citizenship Education by using the Cooperative Learning of Jigsaw model so as to improve learning outcomes of the students in grade VIII.5 SMP Negeri 1 of Pariaman City.
\end{abstract}

Keywords: Cooperative learning, learning activity, jigsaw model

\section{Pendahuluan}

Pendidikan Kewarganegaraan merupakan salah satu mata pelajaran yang memiliki peranan penting dalam rangka karakter pembangunan bangsa. Dalam kurikulum Pendidikan Kewarganegaraan (Depdiknas, 2003) disebutkan bahwa Pendidikan Kewarganegaraan merupakan mata pelajaran yang memfokuskan pada pembentukan diri yang beragam dari segi agama, sosial kultural, bahasa, usia, dan suku bangsa untuk menjadi warga negara Indonesia yang cerdas, terampil, dan berkarakter yang diamanatkan oleh Pancasila dan UUD 1945. Hal ini berarti bahwa Pendidikan Kewarganegaraan merupakan mata pelajaran yang berfungsi sangat strategis dalam rangka menciptakan manusia Indonesia yang berkualitas yang setia pada bangsa dan negara.

Dalam rangka pembentukan peserta didik yang memiliki kompetensikompetensi seperti yang dinyatakan dalam kurikulum Pendidikan Kewarganegaraan tersebut, maka sangat diperlukan proses pembelajaran yang mampu mengkondisikan peserta didik sedemikian rupa sehingga peserta didik dapat belajar secara aktif, baik intelektual dan emosionalnya, maupun fisik dan mentalnya. Proses pembelajaran Pendidikan Kewarganegaraan tidak akan mungkin akan berhasil dengan baik apabila aktifitas peserta didik tidak ada. 
Namun demikian, berdasarkan pengalaman yang penulis temukan dan rasakan dalam kenyataannya di lapangan, terdapat banyak indikasi bahwa peserta didik sering kurang aktif dalam proses pembelajaran Pendidikan Kewarganegaraan. Banyak peserta didik yang kurang berminat membaca materi pelajaran, kurang bergairah belajar, kurang perhatian, dan kurang memiliki kesempatan mengaktualisasikan diri, serta sering mengantuk dalam belajar, terutama pada jam pelajaran siang. Selain itu, peserta didik cenderung menjadi penerima informasi pasif dalam proses pembelajaran, kurang berani mengajukan pertanyaan dan mengemukakan pendapat, serta minimnya tanggung jawab peserta didik terhadap tugas yang diberikan kepada mereka. Di sisi lain, banyak pula ditemukan berbagai masalah dimana upaya yang dilakukan pendidik belum mampu membangkitkan keaktifan peserta didik. Proses pembelajaran cenderung menjadi monoton dan kurang bervariasi.

Kondisi seperti ini juga terjadi di tempat penulis mengajar, yaitu pada kelas VIII.5 SMPN 1 Kota Pariaman. Bila keadaan ini dibiarkan terus terjadi dalam proses pembelajaran Pendidikan Kewarganegaraan tanpa solusi, maka hal ini pasti akan dapat mengakibatkan mata pelajaran ini tidak diminati oleh siswa karena kurang menarik, bahkan membosankan dan pada akhirnya prestasi belajar mereka akan menurun.

Berdasarkan kondisi yang telah dipaparkan di atas maka penulis tertarik untuk memperbaiki kondisi tersebut dengan cara melakukan penelitian tindakan kelas (PTK) pada kelas VIII.5 SMPN 1 Kota Pariaman. Penulis mencoba menggunakan model pembelajaran koperatif dengan teknik Jigsaw yang penulis asumsikan akan dapat memecahkan permasalahan tersebut. Menurut Jhonson (dalam Rianto, 2003) metode pembelajaran koperatif dengan teknik Jigsaw adalah pembelajaran dengan kerja sama kelompok yang masing-masing anggotanya mempunyai tugas dan beban tanggung jawab yang berbeda dengan anggota lain, dimana nanti harus diajarkan kepada anggota lain, sehingga secara bersama-sama berusaha untuk mencapai tujuan yang optimal. Dengan pemakaian metode Pembelajaran Koperatif teknik Jigsaw, proses pembelajaran akan berlangsung dalam suasana yang lebih rileks, namun tetap komit pada rangka kerja yang telah diprogramkan. Peserta didik banyak berhadapan dengan sesama peserta didik, dan tidak terlalu ketergantungan pada pendidik, sehingga keaktifan peserta didik dalam pembelajaran tercipta tanpa paksaan yang pada akhirnya hasil belajar peserta didik menjadi lebih baik.

Berangkat dari paparan di atas, terdapat beberapa permasalahan yang ditemui di kelas. Permasalahan dapat berasal dari peserta didik, guru, suasana belajar dan strategi mengajar. Berdasarkan paparan kondisi di atas maka penulis telah melaksanakan Penelitian Tindakan Kelas untuk mengetahui apakah dengan penerapan metode Pembelajaran Koperatif teknik Jigsaw keaktifan peserta didik akan meningkat. Mengingat adanya berbagai keterbatasan dan agar penelitian ini lebih terfokus, maka penelitian ini dilakukan terhadap peningkatan aktifitas belajar peserta didik pada SMPN 1 Kota Pariaman kelas VIII.5 semester 1 tahun pelajaran 2015/2016. Untuk meningkatkan aktifitas belajar peserta didik tersebut, penulis menggunakan metode pembelajaran koperatif teknik Jigsaw.Rumusan 
masalah yang dikemukakan pada penelitian ini adalah sebagai berikut: Apakah metode Pembelajaran Koperatif teknik Jigsaw dapat meningkatkan aktifitas peserta didik dalam pembelajaran Pendidikan Kewarganegaraan di kelas VIII.5 SMPN 1 Kota Pariaman?.

\section{Tinjauan Kepustakaan}

\section{Belajar Aktif dan Pembelajaran Kooperatif Model Jigsaw}

Dalam setiap proses pembelajaran, pembelajaran aktif sangat dibutuhkan agar materi pembelajaran dapat dikuasai oleh peserta didik. Menurut Silbermen (Silberman, 1999), dalam pembelajaran aktif peserta didik tidak hanya mendengar, melihat, mempertanyakan, mendikskusikan, tetapi juga mengajarkannya pada peserta didik lain. Ketika peserta didik telah mampu mengajarkan pada peserta didik lain, maka pada saat itu materi yang bersangkutan telah makin sempurna dikuasainya. Untuk sampai pada kondisi demikian, antara lain pendidik perlu berupaya memilih metode yang tepat. Lebih jauh Silberman (1999) memaparkan bahwa seorang peserta didik dapat dikatakan telah belajar aktif apabila ia di dalam proses pembelajaran tersebut sudah melakukan sebagian besar pekerjaannya, berfikir menyelesaikan masalahnya, mampu dan berani mengemukakan pendapat dan mengajukan pertanyaan, membuat kesimpulan, menerapkan apa yang dipelajari, mendiskusikan dan mengajarkannya pada orang lain.

Menurut Diedrich (dalam Nasution, 1982), aktifitas yang mungkin dilakukan oleh peserta didik dalam proses pembelajaran adalah:

1. Visual Activities, seperti membaca, memperhatikan, menggambar, demonstrasi, percobaan, dan menyelesaikan tugas, dan sebagainya.

2. Oral Activities, seperti menyatakan, merumuskan berkarya, memberi saran memberikan pendapat, mengadakan interview, diskusi, interupsi, dan sebagainya

3. Listening Activities, seperti mendengarkan uraian, percakapan, diskusi, musik, pidato, dan sebagainya

4. Writing Activities, seperti menulis cerita, karangan, laporan, membuat rangkuman, test, mengisi angket, mengisi lembaran kerja, mengetik, menyalin, mencatat, dan sebagainya

5. Drawing Activities, seperti menggambar, membuat grafik, peta, diagram, pola dan sebagainya.

6. Motor Activities, seperti melakukan percobaan, membuat konstruksi, model, mereparasi, bermain, berkebun, memelihara binatang dan sebagainya

7. Mental Activities, seperti menanggapi, mengingat, memecahkan soal, menganalisis, melihat hubungan, mengambil keputusan, membuat kesimpulan dan sebagainya

8. Emosional Activities, seperti menaruh minat, merasa bosan, senang, gembira, gugup, sedih, kalut dan sebagainya.

Berdasarkan aktifitas-aktifitas di atas maka hal yang paling mungkin dilakukan oleh peserta didik dalam proses pembelajaran Kewarganegaraan adalah: membaca, memperhatikan, menyatakan pendapat, bertanya, mendengarkan uraian, 
membuat rangkuman, menjawab pertanyaan, mengajarkan peserta didik lain, mengisi lembaran kerja peserta didik, mencatat, menanggapi, menaruh minat, senang, gembira, dan berani. Namun demikian, mengingat keterbatasan peneliti dan waktu yang tersedia, maka aktifitas-aktifitas yang diamati pada penelitian ini dibatasi pada aktifitas-aktifitas: mengeluarkan pendapat/bertanya, membaca, memperhatikan, mengajarkan peserta didik lain, dan mengisi lembaran kerja.

Selanjutnya, di sisi lain, pembelajaran koperatif merupakan suatu metode pembelajaran yang mengelompokkan peserta didik atas beberapa kelompok kecil yang anggotanya berkisar antara tiga sampai lima orang. Dalam kelompok mereka mempunyai tugas individu dan kelompok. Setiap anggota kelompok tidak hanya berkewajiban menguasai materi yang menjadi tanggung jawab, tetapi juga berkewajiban mengajarkannya kepada anggota kelompok yang lain. Metode pembelajaran koperatif ini dapat diterapkan dengan berbagai macam teknik. Slavin (dalam Rianto, 2003) mengemukakan bahwa pembelajaran koperatif dapat diterapkan dengan empat teknik, yakni: Teams Game Tournament (TGT), Student Teams Achievement Division (STAD), Group Investigation (GI), dan Jigsaw. Masing-masing teknik ini memiliki kelebihan dan spesifik masing-masing sesuai spesifikasi materi dan karakteristik pembelajaran.

Jhonson (dalam Rianto, 2003) berpendapat bahwa ada empat prinsip atau dasar yang dapat dijadikan sebagai karakteristik pembelajaran koperatif. Keempat konsep dasar itu adalah: 1) antara anggota kelompok terdapat saling ketergantungan yang positif, 2) di dalam kelompok, masing-masing individu memiliki tanggung jawab yang berbeda dengan anggota kelompok yang lain, 3) terdapatnya interaksi aktif dalam kelompok, dan 4) terciptanya keterampilanketerampilan interpesonal.

Pada pembelajaran koperatif, dalam suatu kelompok terdapat saling ketergantungan yang positif antar anggota kelompok. Artinya, masing-masing anggota kelompok saling belajar satu sama lainnya, sehingga semua anggota bekerja sama untuk mencapai tujuan kelompok. Tiap-tiap anggota memberikan kontribusi pada ketercapaian tujuan semua anggota kelompoknya. Setiap anggota mempunyai bahagian tanggung jawab sendiri yang berbeda dari anggota lain. Setiap tanggung jawab anggota tersebut merupakan sistem dari sistem kelompok. Tidak satu anggota kelompokpun yang dapat berpeluang menjadi penumpang gelap.

Seperti telah dikemukakan sebelumnya, salah satu bentuk pembelajaran koperatif adalah pembelajaran model Jigsaw. Pada pembelajaran koperatif model Jigsaw, peserta didik dibelajarkan dan membelajarkan. Artinya, seorang peserta didik tidak hanya belajar untuk menguasai materi pelajaran yang menjadi tanggung jawabnya, tetapi juga berkewajiban mengajarkannya kepada peserta didik lain di kelompoknya. Disamping itu, ia juga harus belajar dari teman kelompoknya untuk materi yang lain. Etin (2000) mengemukakan bahwa dalam pembelajaran koperatif dengan model Jigsaw, suatu informasi diolah oleh peserta didik secara bersama-sama, sekaligus meningkatkan keterampilan berkomunikasi. Selain berkewajiban menguasai materi yang menjadi tanggung jawabnya, peserta didik juga berkewajiban mengajar kepada teman sekelompoknya. 


\section{Pendidikan Kewarganegaraan}

Pendidikan Kewarganegaraan merupakan salah satu mata pelajaran yang bertujuan untuk membentuk peserta didik yang memiliki kecerdasan, baik kecerdasan intelektual maupun kecerdasan emosional, sehingga mereka mampu bereaksi positif dan proaktif dalam menanggapi isu kewarganegaraan dalam kehidupan masyarakat, berbangsa dan bernegara, serta mampu bergaul positif dengan bangsa-bangsa lain dlam pergaulan internasional.

Selanjutnya, dalam kurikulum Pendidikan Kewarganegaraan SMP dan MTsN (Depdiknas, 2003) dijelaskan bahwa tujuan Mata Pelajaran Pendidian Kewarganegaraan adalah untuk memberikan kompetensi-kompetensi sebagai berikut: 1) berfikir secara kritis, rasional dan kreatif dalam menanggapi isu kewarganegaraan, 2) berpartisipasi secra bermutu dan bertanggung jawab, dan bertindak secara tegas dalam kegiatan bermasyarakat, berbangsa dan bernegara, 3) berkembang secara positif dan demokratis untuk membentuk diri berdasarkan kepada karakter masyarakat Indonesia agar dapat hidup bersama dengan bangsabangsa lainya, dan 4) berinteraksi dengan bangsa-bangsa lain dalam percaturan dunia secara langsung dengan memanfaatkan teknologi informasi dan komunikasi.

Pendidikan Kewarganegaraan merupakan mata pelajaran yang mempunyai fungsi yang sangat strategis dalam membentuk manusia Indonesia berkualitas yang setia pada bangsa dan negara. Hal ini dengan tegas tertuang dan dijelaskan dalam kurikulum Pendidikan Kewarganegaraan bahwa mata pelajaran Pendidikan Kewarganegaraan berfungsi sebagai wahana untuk membentuk warga negara cerdas, terampil, dan yang berkarakter setiap pada bangsa dan negara Indonesia dengan merefleksikan dirinya dalam kebiasaan berfikir dan bertindak sesuai dengan amanat Pancasila dan UUD 1945. Untuk mewujudkan tujuan dan fungsi tersebut sangat dibutuhkan suatu proses pembelajaran yang dapat membuat peserta didik aktif baik secara intelektual dan emosional, maupun secara fisik dan mental, sehingga diperoleh hasil belajar yang optimal.

\section{Metodologi Penelitian}

Penelitian ini merupakan penelitian tindakan kelas (PTK) dan dilakukan pada SMPN 1 Kota Pariaman untuk mata pelajaran Pendidikan Kewarganegaraan.pada kelas VIII.5 semester 1 tahun pelajaran 2015/2016. Penelitian tindakan kelas ini dilaksanakan pada minggu ketiga bulan Agustus sampai bulan Oktober minggu keempat tahun 2015. Penelitian ini dilaksanakan dalam 2 siklus. Pada penelitian ini peneliti bekerja secara kolaboratif. Pengumpulan, penganalisisan dan penyajian data dilakukan secara berkelanjutan dan bersiklus.

Subjek penelitian adalah peserta didik kelas VIII.5 SMPN Kota Pariaman pada semester 1 tahun pelajaran 2015/2016, dengan jumlah siswa sebanyak 34 orang yang terdiri dari 15 orang laki-laki dan 19 orang perempuan. Alokasi waktu mata pelajaran Pendidikan Kewarganegaraan per minggu adalah 2 jam pelajaran. Sumber data dalam penelitian ini terdiri dari beberapa sumber, seperti peserta didik dan kolaborator. Data yang didapatkan dari peserta didik berupa data aktifitas peserta didik, hasil belajar, dan respon terhadap pembelajaran. Sedangkan 
data dari kolaborator berupa tingkat keberhasilan implementasi Pembelajaran Koperatif Teknik Jigsaw dalam pembelajaran.

Pengumpulan data dalam penelitian ini adalah melalui tes, pengisian lembar observasi, dan pengisian kuesioner. Alat pengumpulan data yang pertama kali digunakan adalah tes kemampuan awal sebelum perlakuan diberikan. Selanjutnya digunakan adalah Lembar Observasi/ Observation sheet dengan metoda pengamatan terstruktur yang digunakan untuk menilai keaktifan/ proses belajar dan diisi oleh observer. Data penelitian ini dianalisis dengan metode analisis deskriptif. Data hasil pengamatan peserta didik oleh observer dijumlahkan dan disajikan dalam bentuk persentase.

\section{Hasil Penelitian dan Pembahasan}

\section{Siklus I.}

Pada siklus I pertemuan pertama kegiatan awal pembelajaran dimulai dengan mempersiapkan suasana kelas yang kondusif untuk mendukung penggunaan metode Pembelajaran Koperatif teknik Jigsaw dalam mengolah informasi/materi yang dibutuhkan. Peserta didik dibagi atas beberapa kelompok kecil yang masingmasing kelompok beranggotakan empat orang. Setiap anggota dalam kelompok diberi tugas yang berbeda dan bertanggung jawab untuk mengajarkannya pada anggota dalam kelompoknya. Guru berperan aktif dalam menfasilitasi tumbuhnya aktifitas belajar peserta didik yakni; dalam hal membaca materi ajar, bertanya/menanggap, mencurahkan perhatian, mengisi lembar kerja, dan mengajar peserta didik lain.

Pelaksanaan penelitian tindakan kelas pada siklus I ini dilakukan dalam dua kali pertemuan. Pada setiap minggu terdapat satu pertemuan. Kegiatan pembelajaran dimulai dengan menyampaikan tujuan pembelajaran yang akan dicapai pada pertemuan ini dan dilanjutkan dengan appersepsi dan motivasi. Pendidik membagi peserta didik atas beberapa kelompok kecil yang setiap kelompok rata-rata beranggotakan 4 orang. Tiap kelompok dibagikan materi pembelajaran serta tugas yang harus diselesaikan, dan dilanjutkan dengan penjelasan tentang langkah-langkah pembelajaran Koperatif teknik Jigsaw. Kelompok diharuskan membagi tugas, sehingga masing-masing anggota memiliki tanggung jawab untuk menyelesaikan tugas tertentu yang menjadi tanggung jawabnya; tidak ada penumpang gelap dalam kelompok. Kemudian peserta didik berusaha menggali informasi, menguasai materi tersebut, dan mengisi lembar kerja yang menyertai lembar informasi. Tahap awal ini disebut dengan tahap koperatif.

Berdasarkan hasil observasi, dapat digambarkan bahwa pembelajaran berlangsung cukup aktif, terutama dari kegiatan membaca dan memperhatikan teman yang sedang mengajar, karena setiap peserta didik mempunyai tanggung jawab yang berbeda, sehingga kelalaian seseorang dapat menyebabkan kerugian terhadap anggota kelompok yang lain. Aktifitas eksplorasi peserta didik dapat 
dilihat ketika mempelajari lembar informasi masing-masing, untuk selanjutnya dibagikan pengalaman belajarnya (mengajarkan) kepada teman di dalam kelompok masing-masing setelah dikonfirmasikan pada tahap ahli dengan teman mereka yang mendapat tugas sejenis. Namun demikian masih ditemukan sebagian peserta didik yang enggan membaca dan mempelajari lembar informasi, sehingga ketika harus mengajarkan temannya ia tidak mampu. Disamping itu ditemukan juga peserta didik yang melakukan aktifitas lain atau yang permisi ke luar ketika teman-temannya sedang membagikan pengalaman belajarnya (mengajar).

Selanjutnya berdasarkan hasil observasi, terlihat beberapa peserta didik telah mampu menunjukkan aktifitas belajar baik dengan penerapan Pembelaran Koperatif teknik Jigsaw. Hasil dari proses pembelajaran (respons) peserta didik siklus I dapat dilihat pada Tabel 1 berikut.

\section{Tabel 1. Hasil Analisis Aktifitas Pembelajaran Berdasarkan Respon Peserta didik pada Siklus I terhadap Penerapan Pembelajaran Kooperatif Teknik Jigsaw}

\begin{tabular}{rlrrrrr}
\hline No & \multicolumn{1}{c}{ Pernyataan } & SS & S & RR & TS & STS \\
\hline 1 & Meningkatkan minat belajar & $7 / 70 \%$ & $3 / 30 \%$ & $0 / 0 \%$ & $0 / 0 \%$ & $0 / 0 \%$ \\
2 & Meningkatkan aktifitas belajar & $7 / 70 \%$ & $3 / 30 \%$ & $0 / 0 \%$ & $0 / 0 \%$ & $0 / 0 \%$ \\
3 & Meningkatkan partisipasi dalam & $9 / 90 \%$ & $1 / 10 \%$ & $0 / 0 \%$ & $0 / 0 \%$ & $0 / 0 \%$ \\
& $\begin{array}{l}\text { pembelajaran } \\
4\end{array}$ & & & & & \\
5 & Mempermudah pemahaman & $8 / 80 \%$ & $2 / 20 \%$ & $0 / 0 \%$ & $0 / 0 \%$ & $0 / 0 \%$ \\
& lebih baik & $9 / 90 \%$ & $1 / 10 \%$ & $0 / 0 \%$ & $0 / 0 \%$ & $0 / 0 \%$ \\
& $\begin{array}{l}\text { Penggunaan dilanjutkan untuk } \\
\text { konsep lainnya }\end{array}$ & $7 / 70 \%$ & $2 / 20 \%$ & $1 / 10 \%$ & $0 / 0 \%$ & $0 / 0 \%$ \\
\hline
\end{tabular}

Data hasil respon peserta didik di atas menunjukkan bahwa minat dan aktifitas peserta didik yang terjadi pada saat pembelajaran dengan Pembelajaran Koperatif teknik Jigsaw sangat baik, yang dinyatakan oleh hampir keseluruhan peserta didik menjawab setuju dan sangat setuju. Ada 9 orang peserta didik yang menyatakan dengan Pembelajaran Koperatif teknik Jigsaw dapat meningkatkan partisipasi dalam belajar. Pembelajaran terasa lebih mudah, menyenangkan dan jenis pembelajaran yang serupa dilanjutkan pada Kompetensi Dasar yang lain.

\section{Siklus II}

Berdasarkan refleksi pada tahap sebelumnya, masih terdapat permasalahan dalam pembelajaran. Masih terdapat peserta didik yang pasif dan belum memiliki kemampuan untuk menanggap/bertanya, perhatian peserta didik belum optimal, kemampuan mengajarkan oleh peserta didik belum memadai. Fokus permasalahan adalah agar peserta didik dapat memiliki partisipasi yang tinggi dengan aktifitas yang banyak melibatkan dirinya dengan memungkinkan interaksi yang lebih erat. Pada siklus II ini proses pembelajaran masih tetap menggunakan Pembelajaran Koperatif dengan teknik Jigsaw untuk mencapai Kompetensi Dasar yang telah ditetapkan dalam RPP. 
Kegiatan pembelajaran dimulai dengan menyampaikan tujuan pembelajaran yang akan dicapai dan dilanjutkan dengan appersepsi dan motivasi. Pendidik memberikan materi pengantar untuk masuk memahami materi ini pembelajaran sesuai dengan RPP yang telah disiapkan. Peserta didik terlihat sangat siap untuk segera membahas materi yang menjadi bagian tugasnya, karena telah mereka memiliki persiapan, dan tinggal memadukan dan/atau mengkonfirmasikan dengan kelompok ahlinya.

Pembelajaran yang dilaksanakan pada Siklus II ini dirasakan lebih baik oleh peserta didik dibandingkan pada pembelajaran siklus I sebelumnya. Gambaran aktifitas pembelajaran pada siklus II ini secara ringkas dapat dilihat dari Tabel 2 berikut:

Tabel 2. Hasil Analisis Aktifitas Pembelajaran Berdasarkan Respon Peserta didik pada Siklus II terhadap Penerapan Pembelajaran Kooperatif Teknik Jigsaw

\begin{tabular}{rlccccc}
\hline No & \multicolumn{1}{c}{ Pernyataan } & SS & S & RR & TS & STS \\
\hline 1 & Meningkatkan minat belajar & $26 / 77 \%$ & $8 / 23 \%$ & $0 / 0 \%$ & $0 / 0 \%$ & $0 / 0 \%$ \\
2 & Meningkatkan aktifitas belajar & $28 / 82 \%$ & $6 / 18 \%$ & $0 / 0 \%$ & $0 / 0 \%$ & $0 / 0 \%$ \\
& Meningkatkan partisipasi dalam & $30 / 88 \%$ & $4 / 12 \%$ & $0 / 0 \%$ & $0 / 0 \%$ & $0 / 0 \%$ \\
3 & pembelajaran & $25 / 74 \%$ & $9 / 26 \%$ & $0 / 0 \%$ & $0 / 0 \%$ & $0 / 0 \%$ \\
4 & Mempermudah pemahaman & $32 / 94 \%$ & $2 / 6 \%$ & $0 / 0 \%$ & $0 / 0 \%$ & $0 / 0 \%$ \\
5 & Membuat situasi pembelajaran & & & & \\
& $\begin{array}{l}\text { lebih baik } \\
\text { Penggunaan dilanjutkan untuk }\end{array}$ & $30 / 88 \%$ & $4 / 12 \%$ & $0 / 0 \%$ & $0 / 0 \%$ & $0 / 0 \%$ \\
6 & konsep lainnya & & &
\end{tabular}

Data hasil respon peserta didik di atas menunjukkan bahwa minat dan aktifitas peserta didik yang terjadi pada saat belajar dengan Pembelajaran Koperatif teknik Jigsaw terus meningkat secara sangat tanjam. Dari hasil jajak pendapat melalui angket yang disebarkan, terlihat bahwa tidak seorangpun yang merasa tidak setuju ataupun ragu-ragu dengan pembelajaran yang dilaksanakan dengan Pembelajaran Koperatif teknik Jigsaw. Artinya, mereka setuju, bahkan sangat setuju bahwa teknik pembelajaran model Jigsaw ini dapat meningkatkan partisipasi belajar dan membuat situasi pembelajaran lebih baik.

\section{Pembahasan}

Berdasarkan observasi, kuesioner, catatan harian (jurnal), nilai perkembangan nilai tugas (Lembar Kerja) dan tes tertulis yang dilakukan pada kedua siklus selama empat kali pertemuan maka dapat diketahui bahwa penerapan Pembelajaran Koperatif teknik Jigsaw ternyata dapat meningkatkan keaktifan belajar peserta didik kelas VIII.5 di SMP Negeri 1 Kota Pariaman. Pada Siklus I pembelajaran yang dilakukan pendidik belum mampu membangkitkan response peserta didik terhadap materi yang diberikan, baik dari segi jumlah maupun segi kulitas. Selama pembelajaran masih dijumpai peserta didik yang bertanya, 
dan/atau menanggapi hanya asal-asalan, bahkan ada yang hanya sekedar bertanya tentang istilah. Kesiapan untuk belajar kurang dan membutuhkan persiapan awal yang lebih matang. Pendidik memberikan dorongan agar peserta didik ikut terlibat aktif dan berani dalam mengungkapkan pendapat. Selain itu, aktifitas membaca oleh peserta didik dalam rangka mengeksplorasi materi pelajaran masih belum terlihat sesuai dengan harapan. Dalam proses pembelajaran masih ditemukan peserta didik yang bercanda, mengantuk, izin keluar kelas, atau melakukan kegiatan lain pada saat teman kelompoknya membaca materi ajar.

Untuk mengatasi kejenuhan peserta didik tersebut, pendidik memberitahukan lebih awal materi yang menjadi tugas dan tanggung jawabnya seminggu sebelum pembelajaran. Hal ini dilakukan agar peserta didik lebih leluasa dan tidak terdesak untuk menguasai materi ajar, serta kegiatan membaca yang dilakukan peserta didik di luar jam pelajaran lebih bebas. Pada pembelajaran di Siklus II kegiatan membaca pada Kelompok Koperatif terlihat lebih bersemangat. Peserta didik melakukan kegiatan membaca materi ajar guna menambah persiapan yang telah dimilikinya, dan ditemukan juga peserta didik yang bekerja keras membaca menguasai dan mendalami materinya dengan alasan untuk mengantisipasi kebuntuan dalam menjawab tanggapan-tanggapan peserta didik lain; serta agar dapat mengajar dan menyampaikan presentasi lebih baik lagi.

Berdasarkan hasil analisis dan evaluasi lembar observasi, dan dipadukan dengan jurnal/catatan harian terlihat dengan jelas bahwa indikator-indikator keaktifan belajar peserta didik telah meningkat pada siklus II dibandingkan dengan pembelajaran pada siklus I. Peserta didik makin berani bertanya/menanggap, aktif membaca dalam rangka mengeksplorasi materi ajar, perhatian peserta didik dalam pembelajran makin intensif, sebagian besar telah mengisi lembar kerja dengan baik, dan kemampuan mengajarkan temannya yang juga menampilkan kemampuan berkomunikasi lisan peserta didik juga sudah mengalami peningkatan.

Dengan demikian dapat dipahami bahwa ternyata pembelajaran koperatif teknik Jigsaw dapat membuat pembelajaran lebih menarik, apalagi bila dibarengi dengan penggunaan media pembelajaran yang menarik. Hal ini sesuai dengan pendapat Yamin (2008) bahwa media pembelajaran memiliki mafaat untuk menjadikan proses pembelajaran lebih menarik. Media dapat membangkitkan rasa keingintahuan peserta didik, membantu menghidupkan suasana kelas dan terhindar dari suasana monoton dan membosankan.

Penerapan Pembelajaran Koperatif dengan teknik Jigsaw yang diiringi dengan pemberian waktu yang cukup serta pembelajaran yang menggunakan slide bergambar/video dapat meningkatkan aktifitas peserta didik. Kreatifitas peserta didik menyelesaikan tugas yang diberikan juga terakomodir. Hal ini ditandai dengan bervariasinya sumber belajar yang digunakan sebagai referensi dan variasi bentuk bahan ajar yang disajikan.

Dengan demikian dapat dikatakan bahwa penerapan pembelajaran koperatif teknik Jigsaw akan membuat kegiatan pembelajaran berlangsung secara tepat guna dan berdaya guna sehingga hasil belajar peserta didik dapat ditingkatkan. Akhirnya dapat disimpulkan bahwa rendahnya keaktifan peserta didik yang 
memberikan dampak pada hasil belajar peserta didik terpecahkan pada akhir siklus II dengan meningkatnya aktifitas di kedua siklus dan memiliki korelasi positif.

\section{Penutup}

Berdasarkan hasil penelitian dan pembahasan terhadap hasil penelitian tindakan kelas ini maka dapat ditarik beberapa kesimpulan aantara lain:

1) Pembelajaran yang dilaksanakan oleh guru dengan menerapkan Pembelajaran Koperatif teknik Jigsaw ternyata dapat meningkatkan keaktifan belajar yang bermuara pada naiknya hasil belajar peserta didik pada pembelajaran Pendidikan Kewarganegaraan,

2) Pembelajaran yang dilakukan secara berkelompok dengan jumlah peserta didik yang tidak terlalu banyak akan dapat membuat peserta didik atau kelompok lebih terarah untuk mengikutinya,

3) Pembelajaran dengan memberikan waktu yang cukup kepada peserta didik untuk belajar sebelum dibelajarkan, menjadikan peserta didik lebih siap, menguasai materi ajar, percaya diri, dan aktif.

4) Pembelajaran yang menyenangkan dan mampu menfasilitasi keaktifan belajar dapat menumbuhkan kreatifitas dan iklim kompetisi yang sehat di kalangan peserta didik.

Berdasarkan kesimpulan di atas maka dalam tulisan ini dapat pula dikemukakan beberapa saran, antara lain:

1) Pendidik hendaknya senantiasa berupaya memfasilitasi keaktifan belajar peserta didik, karena keaktifan dapat meningkatkan hasil belajar .

2) Pendidik hendaknya selalu menciptakan suasana belajar yang menyenangkan, agar peserta didik dapat dengan leluasa mengembangkan potensinya.

3) Pendidik diharapkan dapat memberikan waktu yang cukup bagi peserta didik belajar dan mempersiapkan diri sebelum dibelajarkan menjadikan peserta didik lebih siap, menguasai materi ajar, percaya diri, dan aktif dalam proses pembelajaran.

\section{DAFTAR KEPUSTAKAAN}

Depdiknas. (2003). Standar Kompetensi Mata Pelajaran Pendidikan Kewarganegaraan SMP dan MTSN. Jakarta: Depdiknas.

Etin, Solihin. (2000). Pengembangan Model Cooperatif Learning. Jakarta: Lembaga Penelitian Universitas Jakarta.

Nasution, S. (1982). Berbagai Pendekatan Dalam Proses Belajar dan Mengajar. Jakarta: Bumi Aksara.

Rianto, Milan. (2003). Metode Pembelajaran. Malang: Lembaga Penelitian IKIP Malang. 
Silberman, Mel. (1999). Active Learning, 101 Strategi Pembelajaran Aktif. Yogyakarta: Yappendis.

Yamin, Martinis. (2008). Desain Pembelajaran Berbasis Tingkat Satuan Pendidikan. Jakarta: Gunung Persada. 